ARTICOLE

\title{
STATE'S OWN INTERESTS IN THE SPORTS SPHERE AND PUBLIC INTERESTS IN THE SPORTS SPHERE
}

\author{
DOI:10.24193/SUBBiur.62(2017).3.9 \\ Published Online: 2017-09-30 \\ Published Print: 2017-09-30
}

\section{I.V. PONKIN*}

A.I. REDKINA**

\begin{abstract}
The article is devoted to research of the state's own interests in the sports sphere. The purpose of this article is to research relevant interests of the state in supporting sports and providing of adequate legal regulation in this sphere, as well as to research public interests in this sphere. The article examines main scientific approaches to this issue, examines using sports as a political tool by the state.

Main categories of state interests in the management of sports and the use of sports are determined in this article. These interests are: foreign policy and foreign economic interests, domestic interests.

The article shows the importance of this issue for determining objectives of public administration in the sports field. Authors describe public interests in the sports field.

It is concluded that sport provides required resources for public authority: economic resources, image resources, as well as resources that provide social solidarity. It is also concluded that proper consideration of public interests in public administration in sports sport predetermines proper quality of such public administration, its adequacy, rationality, and efficiency.
\end{abstract}

Keywords: interest, public interest, public administration in sports sphere, administrative law, sports law, legal regulation in the sports sphere, lex sportiva, sport, autonomy of sport.

One of the most important issues of general public administration theory (in relation to sports) is the motivation of the state in public administration and government policy in sports, in making decision about how much and to what degree the government should interfere (or, on the contrary, stay away from) sports affairs.

According to the approach suggested by D.N. Bakhrakh, B.V. Rossinskiy and Yu.N. Starilov, "the theory of interests determines the types of interests, which are provided by certain legal provisions (law principles), and identifies the areas of legal regulation of specific public interests or activities. This theory aims, first of all, at revealing the public interest, ensured by the established legal relationships. Public law serves government (public) 
interests, while private law regulates private interests... The theory of interests only touches upon the most general aspects of distinguishing between public (administrative) and private (civil) laws. It does not provide any complete and clear distinction between these public law entities, because most legal provisions regulate both public and private interests at the same time"1.

Apart from the imperatives of the government participation in managing relationships in the sports sphere and assistance of the state in the sports development, provided by law, there are also direct national interests for sports and in the field of sports, as well as public interests in the field of sports. Certain administrative and legal functions of the government are related to these interests. The above to a large extent relates to the resource potential of sports and significance of sports for the state, as well as other specifics of sports, which cannot be ignored by public authorities whatsoever.

At the same time, the concept of "the development of sports", from our perspective, is interpreted according to the definition provided by Michael Collins, who describes the development of sports as a process, which leads to an increase at all levels of possibilities and efficiency of processes, systems, and structures created to make people (in general, or certain groups, or in certain areas) to participate in sports or sports and recreation activities and/or encourage such participation ${ }^{2}$.

\section{National Interests in the Field of Sports}

The degree of government's commitment in sports throughout history has been different depending on the country and its political regime.

Traditionally, sports have been used by authorities mostly in military training of army officers.

Sports and sports activities have been usually used by the government as instruments for achieving various goals, for example, spectator sports were used as public holiday entertainment for masses. In addition, sports in different ways have been used for political propaganda ${ }^{3}$.

According to Raymond Sauer, in Ancient Rome sports were used as a monument to political competition. Then, upon the fall of the political regime, it lost its destination. The above author provides a number of other examples when sport is used as a political instrument in various ways. For example, a government can regard sports as the means to enhance people's physique and skills for military purposes, both for defense and aggressive wars. In England the nationals that were engaged in bow shooting were preferred. At the same time, other kinds of sports fancied by the people were often prohibited. For example, Edward IV banned cricket (in its early form) because it distracted the people from bow shooting. Golf was banned in Scotland for the same reason. Henry VIII even issued a decree obliging all fathers to develop the necessary skills in their sons and provide them with the required equipment (a bow and arrows). However, despite the fact that bow shooting was very popular in England, history shows that the monarchy's attempts to 
prevent people from participating in the preferred kinds of sports failed. The most distinguished kind of sport, which monarchy did not approve of, was a predecessor of modern football popular with common people. This kind of sport, born in the UK, which later became the most popular kind of sport in the world, had been repeatedly banned from 1314 to 1667 (over 30 times). The most extreme examples of the government's interventions into sport are dictator regimes of the $20^{\text {th }}$ century. Thus, Mussolini saw sport as an essential way to "revive and unite" Italy into a hypercentralized state and, although he was not himself interested, for example, in football per se, he recognized the abilities of such kinds of sports to affect mass public. The government restructured the national league, launched a large-scale stadium construction program, invested into the national team (strange as it may be, partly by hiring overseas players), and made sure the media were motivated to cover the events that were taking place ${ }^{4}$.

An aggressive lobbying campaign yielded Italy a victory in the competition for the right the hold the second World Cup in 1934. The Italian national team not only had foreign players, but also a great number of professionals from the national clubs. At the same time, most players did not take national competitions seriously and often refused to take part in them. However, under Mussolini's regime significant efforts were made so that the best players would contribute to the regime's image by playing for their team. From 1934 to 1938, Italy won two international cups and Olympic gold. Like many other leaders, Mussolini made efforts to be systematically seen and photographed with his winning team. According to Raymond D. Sauer, more attractive image was established for calcio, which was actively used under the fascist regime in Italy as an instrument of propaganda. Hitler also took part in implementing similar projects in Germany. As in Italy, in Germany sport was used as an important instrument of propaganda in the Third Reich for the purposes of building a strong society. In particular, high hopes were had for the Olympic Games in Berlin in $1936^{5}$.

The Olympic Games of 1936 can to a great extent be regarded as an illustration of using sports by the government for political purposes. Hitler used sports along with political education to inspire youth to build a "new order". He also regarded the Olympic Games as an effective way to promote the regime's ideology6.

At the moment, sport is used in this way in many world countries and the factors, which led to this in the past, still remain relevant.

Thus, entertaining athletic competitions, used to attract significant audiences for the purposes of political activities, have required and still require relatively little resources ${ }^{7}$.

According to Victor Cha, sport is not merely an instrument of expressing national identity. In some cases positive athletic reputation may enhance the country's global status and its stature on the global stage. From this perspective, high sports results become the "power assets» of the state ${ }^{8}$.

The level of professional development of sports obviously plays a great part in the country's international image. Similarly, the level of professional sports' development, availability of a signature sports club, accommodation and training of a world class professional athlete can be also significant for the image of a city, area, or district. 
The impact made through holding such international sporting events as the Olympic Games or the World Football Championship, according to a number of researches, can be regarded in the political sphere as a kind of applying the so-called "soft power" because the country where this event is held uses it for its own purposes. As an example of such situation Aung Ko Min refers to the 2013 Southeast Asian Games held in Myanmar during this country's democratic transition period ${ }^{9}$.

According to Raymond Sauer, the practice of using the Olympic Games by the government to "make a statement" is also relevant now. This was particularly evident during the Olympic Games in Beijing in 2008. For a politician, sport (his relation to sports) is a powerful way to enhance the level of his awareness and popularity among people, in particular, because the attention of the media is traditionally largely focused on sports. This is especially relevant in such countries as the USA, where the President meets the most talented and popular athletes in the White House, as well as in autocratic countries, where the stadiums are decorated with enormous posters of their national leaders. Raymond D. Sauer gives the following interesting example of the way sports can be used for political purposes to attract people's attention. Regular hearings are held in the United States Congress on sports issues with participation of sports leaders, for example, to discuss how the National Football League ensures that the rules of the game are observed. At the same time, the US Congress itself plays minimum part in implementing public administration in sports in this country, and the rules of the game are presumed and are an indefeasible sports component, free from government influence, in the USA. In addition, the results of such hearings are quite abstract. However, they are held to enhance sports people's popularity ${ }^{10}$.

Therefore, sport provides the necessary resources to public authorities such as economic, image resources, and the resources ensuring social solidarity.

As Chien-Yu Lin, Ping-Chao Lee and Hui-Fang Nai put it, government interference with the field of sports today is in no small measure made to demonstrate social, political or economic living standards of this country ${ }^{11}$.

According to K.A. Alexeyev, "the country's sports image is based on history, and cannot exist out of the historic retrospective context"12. The following quote is attributed to US President John F. Kennedy. "The country's prestige is truly determined by two things: flying to the Moon and gold Olympic medals"13.

In the context of foreign policy, sport is often used to achieve specific goals in certain situations. Thus, China initiated cooperation in sports to show its strive for closer relationships with the West during the Cold War. Sports can also be used in foreign policy as a means to demonstrate disagreement with certain policies of other countries. This has also often taken place in history. Moreover, sports started to play an important part in foreign policy of world countries due to the two following reasons. First of all, sports diplomacy, which combines the aspects of social and cultural diplomacies, is somewhat beyond the traditional diplomacy boundaries, which contributes to enhancing diplomatic relations among nations, and, secondly, sports can also be used as an instrument of "forcing" diplomacy ${ }^{14}$.

Sport can also be regarded by the government as a way to keep the workforce in healthy condition and a way to reduce healthcare expenses, which is especially relevant 
for industrially developed states, where there is a demographic problem of ageing of the population. From this perspective, high achievement sport assists in fulfilling these goals because it motivates the relevant public to practice sports ${ }^{15}$.

Sport encourages economic development because it has high economic potential because it involves, in particular, athletic goods manufacture, arrangement and holding of sporting events, rendering of sports-related services. Moreover, sport is also a potential catalyst of economic development, because, among other things, physically active population is healthier, and its production capacity is higher. Sport also aids economic development by providing cheaper ways to give work prospects, especially among young people, which, in its turn, helps to lower youth crime levels ${ }^{16}$.

Investing into the country's sports achievements is a development instrument used to enhance the country's infrastructure, not just the one relating directly to sports (sports facilities, stadiums, etc.), but other physical infrastructure such as highways, railways, airports, ports, telecommunications, hotels ${ }^{17}$.

Consequently, it is reasonable to identify the following main groups of national state interests in sports administration and using sports as a political instrument ${ }^{18}$ :

\section{1) foreign policy interests and foreign economic interests:}

- country's reputational interests, making, maintaining and development of country's positive image in the international arena;

- interest of using sport as a way to establish (initiate) or maintain relations with other countries;

- interest in promoting one's own interests and goals at the global level;

- interest of using sport as a "forcing" diplomacy means, as a "soft power" instrument (in the positive sense of this concept);

\section{2) domestic interests:}

- interest of using sport as a way to maintain population's health to reduce healthcare expenses;

- interest of using sport as an instrument of physical and mental preparation of population masses for long-term purposes to ensure the country's defense capabilities;

- interest of using sport as a means to ensure leisure and recreation of population (in order to meet its interest in employability and productivity of the population, and because of the imperatives of the welfare state);

- interest of using sport as a means to ensure economic development of different regions of the country and the country as a whole as a result of developing the field of sports (as an industry) on its own, but also because its development acts as a catalyst for the development of other fields, provides employment of the population;

- interest of using sport as a means to promote the regime's interests and values at the national (central, federal) level among population;

- interest of using sport as a means to ensure population's loyalty to the government's policy and a way to provide additional contribution into legitimacy of the authorities; 
- interest of using sport as an inhibitor (moderator, "restrainer") and a means to prevent radicalism and extremism among children and young people and in the society in general;

- interest of using sport as a means to ensure social integration, inculturation, moral and patriotic education of the younger generation and the population as a whole, as well as a means to ensure social solidarity;

- interest for using sport as a way of constructive redirecting (channeling) the social energy of the masses.

\section{Public interests in the sports sphere}

According to a well-grounded opinion of A.B. Zelentsov, "a lawful state is a country, where public administration, represented by its authorities and officials, acting within the competence provided by law, implements a public interest as part of administrative procedures through actions and decisions made based on and pursuant to the law, and controlled by administrative justice institutions"19.

Public interests are also present in sports, determining certain responsibilities of the country.

As R.D. Grebnev reasonably puts it, "an important factor determining the specifics of social relations in sports, and, more specifically, legal relationships in the field of sports is a complex relation between private and public interests in this field, definitive dominance of public interests at the core of building the entire system of sports relations and sports-related relations" 20 .

According to D.N. Bakhrakh, B.V. Rossinskiy and Yu.N. Starilov, basically, one of the specific features of administrative law is its aim to ensure public interests and implement government functions and tasks. "All key qualities inhering to public administration reflect in administrative-legal relations, as well as public interests implemented over the course of practical performance of functions by the executive authorities... The administrative law itself, first of all, aims to express, defend, and ensure public interests", this is one of the essential functions of the administrative law; "administration acts as the main form of administration aim to pursue interests of the entire society, its social groups, interests of the country itself and its citizens"21. At the same time, according to these authors, "public interests are established and pursued in the administrative law using such legal means as 1) legal regulation of the public interest, identifying its specific features, implication and types; 2) regulatory documentation of the need to recognize public interests' priority, their ubiquitous, mandatory and direct observance, and establishing the forms and types of legal defense of public interests; 3) identifying legal liability for violating public interests. Consequently, administrative-legal regulation covers an enormous sphere of public interests"22.

Article 1 of the General Law of Mexico dated 05.06.2013 (revised on 01.06.2016) "On physical culture and sport", Article 2 of the Law of Spain dated 15.10.1990 No. 10/1990 (revised on 01.05.2015) "On sports", as well as many other foreign laws on sports cover public interests in sports. 
Yu.A. Tikhomirov makes the following statement. "What are public interests? In the strict sense, these are common interests, some sort of averaging of individual, group interests. These are social interests, without fulfilling which, on the one hand, private interests cannot be pursued, and on the other hand, integrity, sustainability, and normal development of companies, governments, nations, social strata, and finally, society in general are impossible. These are officially recognized interests supported by the state and having juridical protection. Therefore, the public interest is a social community interest recognized by the state and secured by the law, fulfillment of which is a condition and guarantee of its existence and development"23.

According to R.D. Grebnev's interpretation, "the public interest is recognized (or formed and therefore objectively documented as such and subject to recognition), secured, safeguarded, and protected by public authority (public authorities of several countries), as an expresser and representative of social interests, major (generally valid, of national or international significance) integral set of legal, social, economic, and/or other interests (needs, aspirations, and future expectations-intentions) of the society as a whole or the interests of individual social strata significant for the society... Public interests in sport, provided they are duly (in detail, consistently, clearly) formulated, actually jointly form an axiological and conceptual core of public administration and government policy in sport... Public interests closely relate to foreign policy and domestic policy affairs of the country being both its axiological and conceptual, deontological basis, and the criteria of measuring qualities at a certain period of time (or at a certain stage of country's development) as part of the specific aspect (specific aspects)"24.

According to the Activity Plan of the Ministry of Sports of the Russian Federation for 2016-2021 ${ }^{25}$, "general focus of the government's policy in the field of physical culture and mass sports, among other things, ensures 4 national interests (according to our concept, public, - author's note), specified in the National Security Strategy of the Russian Federation dated 31.12.2015²6:

- strengthening national defense, ensuring inviolability of the constitutional order, sovereignty, independence, governmental and territorial integrity of the Russian Federation;

- strengthening of national consent, political and social stability, development of democratic institutions, improving the ways of interaction between the government and the civil society;

- increasing the living standards, promotion of the population's health, ensuring stable demographic development of the country;

- increasing competitive ability of the national economy".

R.D. Grebnev identifies the following generalized public interests in sport ${ }^{27}$ :

1) a set of public interests in sport, determining the deontological basis for recognizing sport by the government, attitude towards it and building government policy in this field:

- a group of public interests relating to the state's responsibility to guarantee the constitutional right for sport, integrally including multiple rights (for associations, development, etc.); 
- a group of public interests in the field of protecting population's health and ensuring their healthy lifestyle and physical development;

- a group of public interests in the field of demography, ensuring safety and protection from domestic threats;

- a group of public interests relating to upbringing and inculturation of the population, generation and strengthening of social values, social morale including encouragement of social life and forming and reproduction of the national idea;

- a group of public interests relating to social integration and providing equal social opportunities for the citizens (including persons with disabilities) and social groups, forming and development of social solidarity, reduction of social and cultural inequality;

- a group of public interests relating to moral upbringing and socialization of minors, arrangement of their leisure activities and filling them with positive content;

- a group of public interests relating to organization of fight against extremism, other crime and violence across the population (first of all, among children and young people), taking of drugs and alcohol abuse;

- a group of public interests relating to reproduction, protection, safeguarding, strengthening, and development of the country's domestic image (including the media component, which nowadays has become an integral part of the image);

- a group of public interests in the field of economic, tourist, and cultural development (at the level of the country, regions and local communities) through mechanisms of sports development of territories and providing employment of the population;

2) a set of public interests directly relating to pursuing sports activities (public interests within the sports system):

- a group of public interests relating to ensuring law enforcement and legitimacy in sports and in sports fans' environment;

- a group of public interests relating to ensuring morality and honesty in sports, observance of Fair Play principles;

- a group of public interests relating to inadmissibility of using doping substances;

\section{3) public interests relating to international relations:}

- a group of public interests in the field of national defense and ensuring safety and sovereignty, protection from external threats;

- a group of public interests relating to reproduction, protection, safeguarding, strengthening, and development of the country's international image.

Proper consideration of public interests in public administration in the field of sport predetermines proper quality of such public administration, its adequacy, rationality, and efficiency. 
* Doctor of science (Law), professor of Sports Law Department of the Kutafin Moscow State Law University, State professor; i@lenta.ru.

** PhD (Law), lecturer of Sports Law Department of the Kutafin Moscow State Law University; juriste.ap@gmail.com.

${ }^{1}$ D.N. Bakhrakh, B.V. Rossinskiy, Yu.N. Starilov (2005) Administrative law, Textbook, 2-nd edition, revised and amended, Moscow, Norma, pp. 60-61.

${ }^{2}$ M. Collins (1995) Sports Development Locally and Regionally, Reading (Berkshire, UK), Institute of Leisure \& Amenity Management, p. 21.

${ }^{3}$ R.D. Sauer (2008) Sport, the State, and the Market, Occasional Paper, No 49, p. 7.

${ }^{4}$ R.D. Sauer (2008) Sport, the State, and the Market, Occasional Paper, No 49, pp. 8-9.

${ }^{5}$ R.D. Sauer (2008) Sport, the State, and the Market, Occasional Paper, No 49, pp. 9-10.

${ }^{6}$ K.A. Min (2015) Sport as a tool of politics: A study on Myanmar's Southeast Asian Games 2013: A Thesis in Partial Fulfillment of the Requirements for the Degree of Master of International Relations, <http://researcharchive.vuw.ac.nz/xmlui/bitstream/handle/10063/4712/thesis.pdf?sequence=1>, p. 21.

${ }^{7}$ R.D. Sauer (2008) Sport, the State, and the Market, Occasional Paper, No 49, p. 7.

${ }^{8}$ V.D. Cha (2009) Beyond the final score: The politics of sport in Asia, New York: Columbia University Press, p. 47.

${ }^{9}$ K.A. Min (2015) Sport as a tool of politics: A study on Myanmar's Southeast Asian Games 2013: A Thesis in Partial Fulfillment of the Requirements for the Degree of Master of International Relations, <http://researcharchive.vuw.ac.nz/xmlui/bitstream/handle/10063/4712/thesis.pdf?sequence=1>, p. 9 .

${ }^{10}$ R.D. Sauer (2008) Sport, the State, and the Market, Occasional Paper, No 49, pp. 10-11.

${ }^{11}$ C.-Y. Lin, P.-C. Lee, H.-F. Nai (2009) Theorizing the Role of Sport in State-Politics, International Journal of Sport and Exercise Science, Vol. 1, No 1, p. 23.

12 K.A. Alexeyev (2009) Sports element of a country's image, Country's image, image of a region: modern approaches, New ideas in communication theory and practice: Collection of research papers, No 3, Saint-Petersburg.

${ }^{13}$ Quoted after: S.V. Kuzmin (2003) Criminal liability for bribery of the participants and organizers of professional athletic competitions and spectator commercial contests: Dissertation of a PhD (Law), Moscow, p. 20.

${ }^{14}$ K.A. Min (2015) Sport as a tool of politics: A study on Myanmar's Southeast Asian Games 2013: A Thesis in Partial Fulfillment of the Requirements for the Degree of Master of International Relations, <http://researcharchive.vuw.ac.nz/xmlui/bitstream/handle/10063/4712/thesis.pdf?sequence=1>, pp. 20-21.

${ }^{15}$ H.E. Meier, The Rise of the Regulatory State in Sport, <http://regulation.upf.edu/ecpr-05papers/hemeier.pdf $>$, p. 3.

${ }^{16}$ Sport as a Tool for Development and Peace: Towards Achieving the United Nations Millennium Development Goals, <http://www.un.org/sport2005/resources/task_force.pdf>, p. 4.

${ }^{17}$ D. Reiche (2014) Investing in sporting success as a domestic and foreign policy tool: the case of Qatar, International Journal of Sport Policy and Politics, p. 2.

18 I.V. Ponkin, A.I. Redkina, O.A. Shevchenko etc. (2017) State administration in the field of sports: Textbook for masters, Moscow, Sports Law Department of the Institute of Contemporary Applied Law of Kutafin Moscow State Law University, pp. 83-85.

${ }^{19}$ A.B. Zelentsov (2015) Administrative law, Moscow, 2015, p. 22.

${ }^{20}$ R.D. Grebnev (2012) Constitutional right for sport, Moscow, p. 102. 
${ }^{21}$ D.N. Bakhrakh, B.V. Rossinskiy, Yu.N. Starilov (2005) Administrative law, Textbook, 2-nd edition, revised and amended, Moscow, Norma, pp. 62, 110, 359.

${ }^{22}$ D.N. Bakhrakh, B.V. Rossinskiy, Yu.N. Starilov (2005) Administrative law, Textbook, 2-nd edition, revised and amended, Moscow, Norma, p. 59.

${ }^{23}$ Yu.A. Tikhomirov (1995) Public law: Textbook, Moscow, BEK, p. 55.

${ }^{24}$ R.D. Grebnev (2012) Constitutional right for sport, Moscow, pp. 107-108.

${ }^{25}$ Activity Plan of the Ministry of Sports of the Russian Federation for 2016-2021, approved by the Minister of Sports of the Russian Federation on 24.05.2016, No. 16, <http://www.minsport.gov.ru/2016/doc/Plan2016_2021.pdf>.

${ }^{26}$ Order of the President of the Russian Federation dated 31.12.2015, No. 683 "On the National Security Strategy of the Russian Federation", Official Gazette of the Russian Federation, 04.01.2016, No. 1 (part II, P. 212).

${ }^{27}$ R.D. Grebnev (2012) Constitutional right for sport, Moscow, pp. 112-113. 